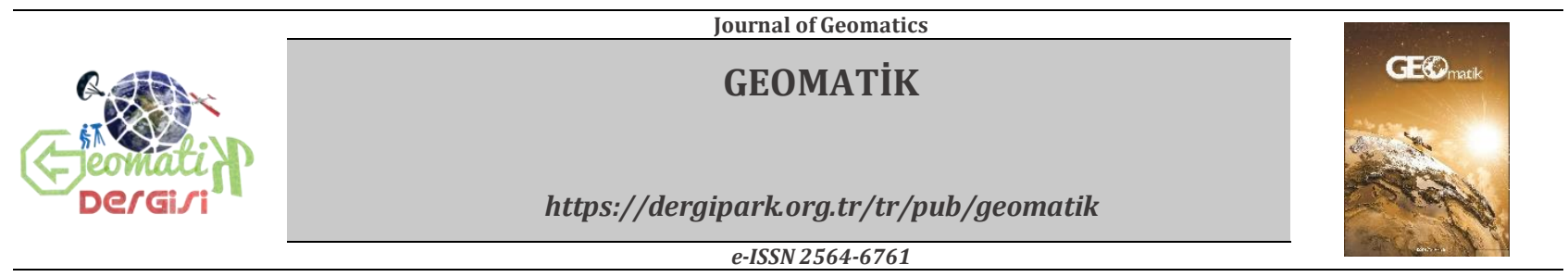

\title{
Lisans ve lisansüstü düzeyinde verilen taşınmaz değerleme eğitiminin değerleme lisansı sınavı kapsamında değerlendirilmesi
}

\author{
Zeynel Abidin Polat ${ }^{1}$, Mehmet Alkan*2
}

1İzmir Katip Çelebi Üniversitesi, Mühendislik-Mimarlık Fakültesi, Harita Mühendisliği Bölümü, İzmir, Türkiye

2Yıldız Teknik Üniversitesi, İnşaat Fakültesi, Harita Mühendisliği Bölümü, İstanbul, Türkiye

\section{Anahtar Kelimeler}

Taşınmaz değerleme Lisansüstü eğitim

Değerleme uzmanlığ SPL
ÖZ

Sermaye Piyasası Lisanslama Sicil ve Eğitim Kuruluşu A.Ş. (SPL) tarafından yapılan gayrimenkul ve konut değerleme lisanslama sınavlarında bașarı yüzdeleri 2016 yılı için \%24.5, 2017 yılı için \% 25.5 ve 2018 yılı için \%30.4'tür. Başarı yüzdelerinin düşük olması sınav içeriği ile verilen değerleme eğitiminin içeriğinin yeterince örtüşmediğini göstermektedir. Bu çalışmada, Türkiye'deki taşınmaz değerleme lisans ve lisansüstü eğitimi hakkında genel bir değerlendirme yapılması amaçlanmış ve bu eğitimin SPL lisanslama sınav konularının içeriğini karșılayıp karșılamadı̆̆ı analiz edilmiștir. Bu bağlamda taşınmaz değerleme ile doğrudan ilișkili olan "Gayrimenkul ve Varlık Değerleme" ya da Gayrimenkul Geliștirme ve Yönetimi” bölümleri ile en çok ilișkili olan "Harita Mühendisliği Bölümü" eğitim içeriği bakımından araștırılmıștır. Araștırma kapsamında taşınmaz değerleme eğitimi veren 28 devlet ve vakıf üniversitesinin web sayfaları 01.01.2019- 01.04.2019 tarihleri arasında incelenmiștir. Bu üniversiteler; ders bazında, lisans ve lisansüstü düzeyinde değerleme eğitimi veren üniversiteler şeklinde gruplandırılmıștır. Çalıșmanın web siteleri üzerinden yapılması ve bazı bölümlerin bilgilerine ulaşılamaması çalışmanın sınırlılığıdır. Araștırmada bölümlerin; lisans ve lisansüstü programlarının müfredatlarında zorunlu/seçmeli dersleri ve akademik kadroları incelenmiștir. Çalışmada ders bazlı tașınmaz değerleme eğitimi veren 16 üniversite incelendiğinde zorunlu ve seçmeli olarak verilen ders sayısının birbirine yakın olduğu görülmektedir. Ayrıca bu dersler genellikle olarak 7. Ve 8. Dönem içerisinde verilmektedir. Ders içerikleri ise yoğun olarak SPL lisanslama sınav konu başlıklarından olan "Gayrimenkul Mevzuatı" ile "Gayrimenkul Değerleme Esasları"na yönelik hazırlanmıștır. Diğer sınav konu bașlıklarına kısmen değinilmiștir. Lisans düzeyinde eğitim veren 6 üniversite vardır. Bu üniversitelerin lisans eğitim içerikleri incelendiğinde derslerin büyük bir çoğunluğunun zorunlu olarak verildiği görülmüștür. Derslerin dağılımlarına bakıldığında genel olarak "Gayrimenkul Mevzuatı" ile "Gayrimenkul Değerleme Esasları" na yönelik olsa da diğer konu başlıklarını içeren derler de mevcuttur. Lisansüstü eğitim veren üniversite sayısı 5 'tir. Verilen eğitimin tamamı "tezsiz yüksek lisans" kapsamındadır. Yüksek lisans programı ders içerikleri ise "Gayrimenkul Mevzuatı" ile "Gayrimenkul Değerleme Esasları" ağırlıklı olsa da diğer SPL lisans sınavı konularına da yer verilmiștir. Araștırma sonunda; taşınmaz değerlemenin lisans düzeyinde eğitim olarak verilmesinin teşvik edilmesi, akademik kadronun harita mühendisliği dışındaki diğer meslek grupları (ör. İnşat Mühendisliği, Şehir ve Bölge Planlama, İktisat) açısından da zenginleștirilmesi, ders içeriklerinin taşınmaz değerlemenin çok yönlü olduğu göz önünde bulundurularak güncelleştirilmesi, yüksek lisans eğitimin tezli olarak yaptırılması önerilmiştir. 


\section{Evaluation of real estate valuation given in graduate and postgraduate level within the scope of the valuation license exam}

\author{
Keywords \\ Real estate valuation \\ Graduate education \\ Valuation expertise \\ SPL
}

\begin{abstract}
In this study, it is aimed to make a general assessment of graduate and postgraduate education of real estate appraisal, and it has been analysed whether this education meets the content of capital market licensing exam topics. The web pages of 28 state and foundation universities that provide real estate valuation training were investigated between 01.01.2019 and 01.04.2019. These universities are grouped as universities providing valuation education courses, at the graduate and postgraduate level. The fact that the study is done through the websites. Also, the information on some departments is not reached is the limitation of the study. In the research; compulsory/elective courses and academic staff are examined in the curricula of graduate and postgraduate programs. In the study, when the 16 universities that provide course-based immovable valuation training are examined, it is seen that the number of courses given as compulsory and elective is close to each other. Besides, these courses are given in the 7th and 8th semester. The course contents are prepared mainly for the subjects of SPL licensing exam subject to the Real Estate Legislation and Real Estate Valuation Principles. Other exam topics are mentioned in part. Six universities provide education at the graduate level. When the graduate educational contents of these universities are examined, it is seen that most of the courses are given as mandatory. When the undergraduate educational contents of these universities are examined, it is seen that most of the courses are given as mandatory. When the distribution of the courses is examined, although there are predominantly subjects related to the Real Estate Legislation and Real Estate Appraisal Principles, there are also some other topics. The number of universities offering postgraduate education is 4 . All of the training is covered by "non-thesis master". The other two master's program courses are weighted by the Real Estate Legislation and Real Estate Valuation Principles. At the end of the research; encouraging the provision of real estate valuation as bachelor's degree, enriching the academic staff in terms of other professional groups other than map engineering (e.g. Construction Engineering, City and Regional Planning, Economics), It has been proposed to do with thesis.
\end{abstract}

\section{Gíriș}

Gayrimenkul, gelişmiş ekonomilerde finansal bazlı alınan kararların büyük bir bölümüne dayanak oluşturmaktadır (Warren-Myers, 2012; Çay ve Boz, 2018; Sakınç ve Coşkun, 2018). Arazi Yönetiminde Taşınmaz Değerleme ve Kadastro Sempozyumu Sonuç Bildirgesinde ise taşınmaz sektörünün Türkiye'deki ekonomik idari faaliyetlerinin $\% 50$ 'sini aşan çok büyük bir ağırlığa sahip olduğu vurgulanmaktadır. Taşınmaz değerlemenin; kamusal uygulamalar (Ör. Vergilendirme, kamulaştırma, devletleştirme, özelleștirme, toprak düzenlemeleri gibi) ile özel sektör uygulamalarında (Ör. Sermaye piyasası, bankacılık, kredilendirme, sigortacılık) yoğun bir şekilde kullanılması (Açlar vd., 2003; Yomralığlu vd., 2011; Erdem, 2018a) bu iddiayı desteklemektedir.

Taşınmaz değerleme birçok faktörün birlikte değerlendirilmesini gerektiren çok boyutlu bir işlemdir (Poon vd., 2011). Bu durum bilirkişinin teknik ve hukuki açıdan karmaşık bir yapıyı analiz etmesini ve elde edilen sonuçlara göre yorumlamasını gerektirir. Bundan dolayı değerleme sırasında yapılan sentez ve analizler için gerekli olan yöntem ve teknik bilgilerin kullanılması için bazı uzmanlık bilgilerine ihtiyaç vardır (Yomralığlu ve Nişancl, 2006). Bu bağlamda taşınmaz değerleme konusunda faaliyet gösterecek kişilerin bazı özel konularda akademik ve profesyonel eğitim alarak gerekli temel bilgilerle donanmış olması gerekmektedir. Yomralıŏlu ve Nişancı'ya (2006) göre özellikle bir taşınmaz değerleme uzmanının; yoğun bir haritacılı ve istatistik bilgisi yanında taşınmaz değerleme mevzuatı, işletme ekonomisi, şehir ve bölge planlama, genel finans ve yerel yönetimler konuları hakkında da temel bilgiye sahip olması gerekmektedir. Üniversitelerde taşınmaz değerlemeye ilişkin ders, lisans ve lisansüstü düzeyinde verilen eğitimle değerleme uzmanları gerekli bilgilere sahip olabilmektedir.

$\mathrm{Bu}$ çalışmayla Türkiye'deki taşınmaz değerleme lisans ve lisansüstü eğitimi hakkında genel bir değerlendirme yapılması amaçlanmış ve bu eğitimin SPL lisanslama sınav konularının içeriğini karşılayıp karşılamadığı analiz edilmiştir. Bunun için taşınmaz değerleme ile doğrudan ilişkili olan "Gayrimenkul ve Varlık Değerleme" ya da Gayrimenkul Geliștirme ve Yönetimi" bölümleri ile en çok ilişkili olan "Harita Mühendisliği Bölümü” eğitim içeriği incelenmiștir. Araştırma kapsamında taşınmaz değerleme eğitimi veren devlet ve vakıf üniversiteleri incelenmiştir. $\mathrm{Bu}$ üniversiteler; ders bazında, lisans ve lisansüstü düzeyinde değerleme eğitimi veren üniversiteler şeklinde gruplandırılmıştır. Çalışmanın web siteleri üzerinden yapılması ve bazı bölümlerin bilgilerine ulaşılamaması çalışmanın sınırlılığıdır. Araştırmada bölümlerin; lisans ve lisansüstü programlarının 
müfredatlarında zorunlu (Z)/seçmeli (S) dersleri ve akademik kadroları incelenmiștir.

\section{TÜRKIYE'DE TAŞINMAZ DEĞERLEME EĞiTIMİNIN ÖNEMİ ve SPL LİSANSLAMA SINAVI}

\subsection{Türkiye'de Taşınmaz Değerleme Eğitiminin Önemi}

Taşınmazların bilimsel bakış açısı ile güncel ve güvenilir verilere bağlı olarak tespit edilen değerleri, kamulaştırma, vergi hesaplamaları, sermaye piyasası uygulamaları, kentsel dönüşüm ve imar uygulamaları, ayni hak tesisi gibi pek çok faaliyetin dayanağını oluşturmaktadır. $\mathrm{Bu}$ bakımdan taşınmazların gerçek değerlerinin tarafsız, doğru ve güvenli biçimde belirlenmesi, güncel tutulması, kamu ekonomisi, toplumsal yapı, kamu yönetimi ve ülkemizin sürdürülebilir gelişimi için büyük önem taşımaktadır (HKMO, 2012; Erdem, 2017). Dolayısıyla taşınmaz değerleme için gerekli olan bilgi birikimine ve yaşanan sorunları çözümleyebilecek tecrübeye sahip nitelikli insan gücüne ihtiyaç vardır. Gerek bu ihtiyacın karşılanabilmesi gerekse taşınmaz pazarlarının şeffaflığının sağlanabilmesi için ülkelerin sağlıklı işleyen değerleme sistemlerini oluşturması ve sürdürmesi gerekmektedir. Temel amacı bilgi üreten, kullanan, eleştiren ve üretken bir düşünce tarzıyla problem çözebilecek nitelikli insan gücünü yetiştirmek olan lisans ve lisansüstü eğitim ile ihtiyaç duyulan insan kaynağının yetiştirilmesi amaçlanmıştır. Farklı amaçlar için gerekli olan gayrimenkul değerinin tahmin edilmesi için gerekli yeterliğe, yeteneğe ve deneyime sahip olan ve bu tahmini gerçekleştirirken de bağımsız, tarafsız ve objektif davranacağı beklenen kişilere "değerleme uzmanı" adı verilir (Yomralığlu ve Nişancı, 2006; Köktürk, 2009; Çay ve Boz, 2018). Lisans veya lisansüstü eğitim alan kişilerin "Konut veya Gayrimenkul Değerleme Uzmanı" olabilmesi için Sermaye Piyasası Lisanslama Sicil ve Eğitim Kuruluşu A.Ş. (SPL) tarafından düzenlenen sınavlarda başarılı olması gerekmektedir (Nişancı, 2005; Erdem, 2017; Çay ve Boz, 2018; Ertaş, 2018; URL-4).

Gayrimenkul değerleme uzmanının gayrimenkulün değerine ilişkin bir kanıya varabilmesi için gayrimenkulün inşaat tipi, malzemesi, araştırma yöntemleri, mevzuat, finansman, ekonomi, raporlama, müzakere ve ilgili diğer birçok konuda yetenek, tecrübe ve bilgi sahibi olması gerekir (Vandell, 2007; Büyükkaracığan vd., 2017; Çay ve Boz, 2018). Değerleme uzmanından beklenen bu yetenek ve bilgi birikimi taşınmaz değerleme içeriğine sahip lisans ve lisansüstü eğitimle elde edilmektedir. Bu bağlamda verilen lisans ve lisansüstü eğitimin içeriğinin taşınmaz değerleme ve SPL lisanslama sınavına uygun olması oldukça önemlidir. Lisans ve lisansüstü eğitim içeriğin zenginliği SPL lisanslama sınavında elde edilecek başarıyı daha da arttıracaktır.

Taşınmaz değerlemenin eğitiminin önemi ülkemizde gün geçtikçe daha çok hissedilmekte ve dolayısıyla bu alanda yapılan bilimsel çalışmalar çoğalmaktadır. Hışır (2009) çalışmasında Türkiye'de taşınmaz değerleme eğitimi ile harita mühendisliğini arasındaki ilişkiyi irdelemiştir. $\mathrm{Bu}$ bağlamda değerleme uzmanlarının sahip olması gerektiği niteliklerin bir an önce belirlenip ve eğitimim içeriğinin buna göre şekillendirilmesi önerilmiştir. Ertaş (2015) çalışmasında Türkiye'deki taşınmaz değerleme eğitimini irdelemiştir. Çalışmada taşınmaz değerlemenin birçok farklı disiplini içeren bir meslek olduğu vurgulanmaktadır. Bu bağlamada taşınmaz değerleme eğitiminin birçok kurumun ihtiyacına karşılayabilmesi için temel mühendislik, ekonomi, finans ve hukuk bilgilerini içeren yapıya dönüştürülmesi önerilmiştir.

Çay ve Boz (2018) çalışmalarında ülkemizdeki gayrimenkul değerleme uzmanlığı için gerekli yeterlilikleri seçtikleri gelişmiş ülkeler ile kıyaslamışlardır. Çalışmada seçilen ülkelerde şart koştukları eğitim, deneyim ve sınav gereksinimleri açısından değerleme işinin ne kadar ciddi olduğunu ve uzmanlık gerektirdiğini vurgulamaktadırlar. Buna karșın ülkemizde ise sınavdan elde edilmesi gerekli başarı haricinde sadece herhangi bir bölümden üniversite mezunu olma ön şartının varlığı eleştirilmiştir. Bu bağlamda üniversite düzeyinde taşınmaz değerleme eğitiminin, değerleme konusunda gerekli bilgi ve becerilerin edinilmesine katkı sunacak düzeye getirilmesi önerilmiştir.

Erdem (2018b) çalışmasında Türkiye'de taşınmaz değerleme alanında yapılan lisansüstü tezlerinin içeriklerini analiz etmiștir. Bunun için 2017 yılına kadar taşınmaz değerleme alanında tamamlanan 108 adet yüksek lisans ve 18 adet doktora tezi değerlendirmeye alınmıştır. Değerlendirme sonucuna göre değerlemesi yapılacak taşınmazlar sahip olduğu öneminden dolayı değişik disiplinlerin çalışma konusu olmuştur. $\mathrm{Bu}$ bağlamada çalışmada taşınmaz değerlemesi faaliyetlerinin bütüncül bir kurumsal yapılanma kapsamında ve uzmanlar marifetiyle gerçekleștirilmesi önerilmektedir.

\subsection{SPL Lisanslama Sınavı}

Türkiye'nin Avrupa Birliği ile yapmış olduğu Gümrük Birliği anlaşması neticesinde özellikle 90 'lı yılların sonuna doğru ülkemize önemli ölçüde yabancı sermeye girişi başlamıştır (Ertaş, 2015). Sermaye girişi çoğunlukla taşınmazlar üzerinden sağlanmıștır. $\mathrm{Bu}$ gelişmelere paralel olarak taşınmazların değer ile ilgili özelliklerinin güvenilir, gerçek zamanlı ve doğru bir şekilde kaydedilme ihtiyacı ortaya çımıștır. Bu ihtiyacı karșlayabilmek için yabancı sermaye gruplarının Türkiye Hükümetine yaptığı girişimler sonucu Sermaye Piyasası Kuruluna, ülkemiz için gerekli olan değerleme uzmanlarını belirlemek amacıyla 
lisanslama sınavları açma yetkisi verilmiş̦tir (Ertaş, 2015). Lisanslama sınavlarıyla bu ihtiyaç kısmen giderilmiştir. Zaman içerisinde Türkiye'de değerleme eğitiminin verilmesinin gerekliliği bu lisanslama sınavlarıyla anlaşılmaya başlanmıștır. Değerleme alanında yetkili kurum olan Sermaye Piyasası Kurulu (SPK) yaptığı faaliyetler ve düzenlemeler aracılı̆gı ile Türkiye'de gayrimenkul değerlemesi yönlendirmektedir (Sakınç ve Coşkun, 2018). Günümüzde Türkiye'deki pek çok üniversitede ön lisans, lisans, lisansüstü düzeyinde değerleme eğitimi verilmektedir. Türkiye'de taşınmaz değerlemesi yapabilmek için Konut Değerleme Lisansı veya daha geniş kapsamlı Gayrimenkul Değerleme Lisansı alınması şarttır. Bu lisanları alabilmek için SPL tarafından düzenlenen sınavlarda başarılı olmak gerekmektedir (Nişancl, 2005; Erdem, 2017; Çay ve Boz, 2018; Ertaș, 2018).

Konut Değerleme Lisansı alabilmek için gerekli şartlar (URL-1):

- $\quad$ En az 2 yıllık yükseköğretim düzeyinde eğitim almış olmak.

- SPL tarafından düzenlenen "Konut Değerleme Lisansı" sınavından başarılı olmak.

Gayrimenkul Değerleme Lisansı alabilmek için ise gerekli (URL-1):

- $\quad$ En az 4 yıllık yükseköğretim düzeyinde eğitim almış olmak.

- SPL tarafindan düzenlenen "Gayrimenkul Değerleme Lisansı" sınavından başarılı olmak.

Lisanslama sınavları; kağıt ortamında ve elektronik ortamda olmak üzere iki farklı şekilde gerçekleştirilmektedir (URL-2).

\section{TÜRKIYE'DE TASINMAZ DEĞERLEME LISANS ve LİSANSÜSTÜ EĞíTIMİ ÜZERİNE BİR ARAŞTIRMA}

Taşınmaz değerlemeye en çok ilgi gösteren meslek grupları arasında harita mühendisleri, inşaat mühendisleri, şehir plancıları, mimarlar, iktisatçılar, işletmeciler ve finansçılar sayllabilir (Hışır, 2009). Erdem (2018b) çalışmasında 1990-2017 yılları arasında taşınmaz değerleme alanında yapılan 108 yüksek lisans ve 18 doktora tezini irdelemiștir. Yapılan tezlerin 37 tanesi (\%30) "Geomatik Mühendisliği", "Harita Mühendisliği" ve Jeodezi ve Fotogrametri Mühendisliği" Anabilim dallarında yapılmıştır. Bu veriler dikkate alındığında taşınmaz değerleme ile en çok ilişkili olan meslek dalı "Harita Mühendisliğidir".

Taşınmaz değerleme, çoğunlukla mühendislik konularını içermektedir. Taşınmazların değerinin hesaplanmasında gerekli olan konumlarının belirlenmesi, taşınmaza ait imar, tapu ve kadastro bilgilerinin incelenmesi gibi konular harita mühendisliğinin temel konularıdır. Bundan dolayı taşınmaz değerleme ile harita mühendisliği birbirleriyle yoğun ilişki içerisindedir. $\mathrm{Bu}$ ilişkiye bağlı olarak özellikle lisans eğitimi kapsamında yoğunlukla taşınmaz değerleme ve ilgili mevzuat derslerine yer veren tek bölüm harita mühendisliğidir (Hışır, 2009). Taşınmaz değerlemenin ilk yaygınlaştı̆̆ı dönemlerde taşınmaz değerleme eğitimi harita mühendisliği eğitimi sırasında verilen taşınmaz değerleme dersleri ile karşılanmaktaydı. Son yillarda taşınmaz değerlemenin öneminin ve kullanım alanlarının artmasiyla birlikte bu alanda lisans ve lisansüstü düzeyinde eğitim veren yeni programlar açılmaya başlamıştır. Bu programlar genellikle "Gayrimenkul ve Varlık Değerleme", "Gayrimenkul Geliştirme ve Yönetimi", "Gayrimenkul Finansmanı ve Değerleme", "Taşınmaz Değerleme ve Geliştirme" adları ile açlmaktadır.

"Gayrimenkul Değerleme Lisansı" aynı zamanda "Konut Değerleme Lisansı" konularını da kapsamaktadır. Bu bağlamda ön lisans düzeyinde konut değerlemesine ilişkin verilen ders içerikleri büyük çoğunlukla gayrimenkul değerlemeye ilişkin verilen lisans ders içerikleriyle uyumludur. Dolayısıyla bu çalışma da sadece lisans ve lisansüstü düzeyde verilen ders içerikleri analiz edilmiştir.

\subsection{Araştırmanın Amacı}

Taşınmaz değerleme alanında gerekli bilgilerin verilebilmesi ve lisanslama sınavlarında bașarı sağlanabilmesi için verilen eğitimin titizlikle planlanması ve uygulanması gerekmektedir. Üniversitelerden mezun olan öğrencilerin teorik ve pratik alanlara hakim ve taşınmaz sektöründe kolaylıkla iş bulabilecek özelliklere sahip olması oldukça önemlidir (Solmaz vd., 2012). Bundan dolayı, taşınmaz değerleme ile ilgili ders içeriklerinin, akademik kadrolarının, uygulama birimlerinin hem lisanslama sınavına yönelik hem de sektörün ihtiyaçlarına göre düzenlenmesi ve geliștirilmesi gerekmektedir. $\mathrm{Bu}$ çalışmada Türkiye'deki taşınmaz değerleme lisans ve lisansüstü eğitimi hakkında genel bir değerlendirme yapılması amaçlanmış ve bu eğitimin SPL lisanslama sınav konularının içeriğini karşılayıp karşılamadığı analiz edilmiştir. Yapılan analiz sonucunda eğitimin kalitesinin ve sınav başarı yüzdesinin yükseltilmesine yönelik çözüm önerileri sunulmuştur. $\mathrm{Bu}$ çalışmayla taşınmaz değerleme eğitimine ve daha sonra yapllacak benzer çalışmalara katkı sağlanacağı düşünülmektedir.

\subsection{Araştırmanın Önemi}

Çalışma, Türkiye'deki taşınmaz değerleme eğitimine ilişkin içerik (müfredat), akademik kadro, uygulama birimleri kapsaminda genel durum değerlendirmesi sağlayacağı için önemlidir. $\mathrm{Bu}$ çalışma ile taşınmaz değerleme eğitimi veren bölümlerin akademik kadrosunun yeterliliği ve çeşitliliği, uygulama birimlerinin altyapısı ve ders içeriklerinin sektörün ihtiyaçlarına göre güncellenmesinin öğrencilerin nitelikli bir şekilde mezun olmasına katkı sunacağı düşüncesine vurgu 
yapılmak istenmektedir. Sektörün ihtiyacını belirleyebilmek için SPL bünyesinde bir eğitim ve sınav komisyonu kurulmalıdır. Bu komisyon, değerlemeyi kullanan kamu kurumları, özel sektör ve üniversiteler ile koordineli bir şekilde çalışarak taşınmaz değerleme eğitimi ve sınav içeriğini birlikte oluşturabilir.

\subsection{Araştırmanın Yöntemi}

Türkiye'deki taşınmaz değerlemeye yönelik lisans ve lisansüstü düzeyde verilen eğitime ilișkin mevcut durum analizi yapabilmesi amaciyla, taşınmaz değerleme eğitimi veren 28 devlet ve vakıf üniversitesinin web sayfaları 01.01.201901.04.2019 tarihleri arasında incelenmiştir. Bu üniversiteler; ders bazında, lisans ve lisansüstü düzeyinde değerleme eğitimi veren üniversiteler şeklinde gruplandırılmıştır. Araştırmada bölümlerin; lisans ve lisansüstü programlarının müfredatlarında zorunlu/seçmeli dersleri ve akademik kadroları incelenmiștir. Ayrıca verilen derslerin içerikleri lisanslama sınavı konu içerikleri ile klyaslanmıştır. Bunun temel amacı verilen derslerin içeriklerinin lisanslama sınav içeriğiyle ne derece uyumlu olduğunu belirlemektir.

\subsection{Araștırmanın Kısıtları}

Lisans eğitimi kapsamında öğrencilere verilen teorik ve uygulamalı derslerin bir kısmı seçmeli derslerden oluştuğu, bazı programlar seçmeli derslerde uygulama ya da teori dersi sınırlaması belirtmediği için bu programlarda genel bir değerlendirme yapılmıştır. Bazı üniversiteler programlara ait ders içeriklerini dönemlik yayınladıkları, bazılarının sayfalarını güncellemedikleri ve bazılarının da yeni kurulmuş olması nedeniyle 4 yıllık ders içeriklerinin tamamını web sayfalarına koymadıkları tespit edilmiștir. Ders içeriklerinin analizinde zorunlu /seçmeli karşılaştırmasını yapabilmek için bu bilgilere tam erişilebilen bölümler dikkate alınmıştır.

\subsection{Araştırmanın Evren ve Örneklemi}

$\mathrm{Bu}$ araștırmanın evrenini, 28 devlet ve vakıf üniversitesi oluşturmaktadır. Yeni kurulmuş ve henüz öğrenci alımı yapmayan bölümler çalışmanın kapsamı dışında tutularak aktif şekilde taşınmaz değerleme eğitimi veren lisans ve lisansüstü programlarının tamamı araștırma kapsamına dahil edilmiştir.

\subsection{Araştırmanın Bulguları}

Araştırma kapsamında incelenen 28 devlet ve vakıf üniversitesinden 19 tanesi ders bazında taşınmaz eğitimi vermektedir. 6 tanesi lisans programı kapsamında eğitim vermektedir. 5 tanesi lisansüstü programı kapsamında eğitim vermektedir. Okan ve Karadeniz Teknik üniversiteleri hem ders hem de lisansüstü kapsamında taşınmaz eğitimi verdiği için toplam üniversite sayısı hesabında bir kez kullanılmıştır. Ders bazında eğitim veren 19 üniversite Tablo 1'de listelenmiștir. Tablo 1'e göre verilen eğitim örgün ve ikinci öğretim şeklinde gerçekleşmektedir. Yıldız Teknik, İstanbul Teknik, Karadeniz Teknik, Kocaeli, Canakkale 18 Mart, Hacettepe, Artvin Coruh ve Okan üniversitelerinde ilgili dersler zorunlu olarak verilmekteyken Bülent Ecevit, Afyon Kocatepe, Konya Teknik, Necmettin Erbakan, Niğde Ömer Halisdemir, Gümüşhane, Osmaniye Korkut Ata ve Cumhuriyet Üniversitelerinde ise ilgili dersler seçmeli olarak verilmektedir. Bunların dışında Harran ve Erciyes üniversitelerinde ise ilgili dersler hem zorunlu hem de seçmeli olarak verilmektedir. Dersler genel olarak 3. (5. ve 6. dönemler) ve 4 . Sinıfta (7. ve 8. dönemler) verilmektedir. Derslerin lisans eğitiminin son dönemlerinde verilmesi, temel harita bilgisini almış öğrencilerin anlaması açısından daha faydalı olacaktır. Erciyes üniversitesinde verilen zorunlu ve seçmeli derslerin çokluğu ve içerik olarak lisanslama sınavı konularını içermesi buradan mezun olan öğrenciler için avantaj sağlayacaktır.

Tablo 1. Ders bazlı taşınmaz değerleme eğitimi veren üniversiteler

\begin{tabular}{|c|c|c|c|c|}
\hline Dersin adı & Dersin verildiği yükseköğrenim kurumu & $\begin{array}{l}\text { Örgün Öğretim } \\
\text { (Ö.Ö)/İkinci } \\
\text { Öğretim (İ.Ö.) }\end{array}$ & $\begin{array}{l}\text { Zorunlu } \\
\text { /Seçmel } \\
\mathrm{i}\end{array}$ & Yarıyıl \\
\hline $\begin{array}{ll}\text { CBS ile } & \text { Taşınmaz } \\
\text { Değerlemesi } & \end{array}$ & Aksaray Ü., Harita Müh. Böl. & Ö.Ö. & Seçmeli & 8. \\
\hline Gayrimenkul Değerleme & Çanakkale 18 Mart Ü., Harita Müh. Böl. & Ö.ö. ve İ.Ö. & Zorunlu & 7. \\
\hline Gayrimenkul Değerleme & Erciyes Ü., Harita Müh. Böl & Ö.Ö. ve İ.Ö. & Zorunlu & 7. \\
\hline $\begin{array}{ll}\text { Gayrimenkul Değerleme } \\
\text { Uygulamaları }\end{array}$ & Erciyes Ü., Harita Müh. Böl & Ö.Ö. ve İ.Ö. & Seçmeli & $\begin{array}{l}\text { 5., } 6 ., 7 . \\
\text { Ve } 8 .\end{array}$ \\
\hline $\begin{array}{l}\text { SPL Gayrimenkul } \\
\text { Değerleme Esasları }\end{array}$ & Erciyes Ü., Harita Müh. Böl. & Ö.Ö. ve İ.Ö. & Seçmeli & $\begin{array}{l}\text { 5., } 6 ., 7 . \\
\text { Ve } 8 .\end{array}$ \\
\hline $\begin{array}{l}\text { SPL Dar Kapsamlı Sermaye } \\
\text { Piyasası Mevzuatı }\end{array}$ & Erciyes Ü., Harita Müh. Böl. & Ö.Ö. ve İ.Ö. & Seçmeli & $\begin{array}{l}\text { 5., } 6 ., 7 . \\
\text { Ve } 8 .\end{array}$ \\
\hline
\end{tabular}




\begin{tabular}{|c|c|c|c|c|}
\hline $\begin{array}{l}\text { Taşınmaz Geliştirmesi ve } \\
\text { Değerlemesi }\end{array}$ & Okan Ü., Geomatik Müh. Böl. & Ö.0̈. & Zorunlu & 4. \\
\hline Taşınmaz Değerlemesi & Yıldız Teknik Ü., Harita Müh. Böl. & Ö.Ö. ve İ.Ö. & Zorunlu & 7. \\
\hline Taşınmaz Değerlemesi & Niğde Ömer Halisdemir Ü., Harita Müh. Böl. & Ö.Ö. & Seçmeli & 8. \\
\hline Taşınmaz Değerlemesi & Necmettin Erbakan Ü., Harita Müh. Böl. & Ö.Ö. & Seçmeli & 5. \\
\hline Taşınmaz Değerlemesi & Hacettepe Ü., Geomatik Müh. Böl & Ö.Ö. & Zorunlu & $\begin{array}{ll}\text { 7. veya } \\
\text { 8. }\end{array}$ \\
\hline Taşınmaz Değerlemesi & Cumhuriyet Ü., Geomatik Müh. Böl. & Ö.Ö. & Seçmeli & 7. \\
\hline Taşınmaz Değerlemesi & Osmaniye Korkut Ata Ü., Harita Müh. Böl & Ö.Ö. & Seçmeli & 6. \\
\hline Taşınmaz Değerlemesi & Artvin Çoruh Ü., Harita Müh. Böl & Ö.Ö. & Zorunlu & 7. \\
\hline Taşınmazl Değerlemesi & Gümüșhane Ü., Harita Müh. Böl & Ö.0̈. & Seçmeli & 8. \\
\hline Taşınmaz Değerlemesi & İstanbul Teknik Ü., Geomatik Müh. Böl. & Ö.0̈. & Zorunlu & 6. \\
\hline Taşınmaz Değerlemesi & Karadeniz Teknik Ü., Harita Müh. Böl. & Ö.ö. ve İ.Ö. & Zorunlu & 8. \\
\hline Taşınmaz Değerlemesi & Kocaeli Ü., Harita Müh. Böl. & Ö.0̈. & Zorunlu & 8. \\
\hline Taşınmaz Değerlemesi & Bülent Ecevit Ü., Geomatik Müh. Böl. & Ö.Ö. ve İ.Ö. & Seçmeli & 7. \\
\hline Taşınmaz Mal Değerlemesi & Harran Ü., Harita Müh. Böl. & Ö.ö. ve İ.Ö. & Zorunlu & 5. \\
\hline $\begin{array}{l}\text { Taşınmaz Mal Değerlemesi } \\
\text { Uygulaması }\end{array}$ & Harran Ü., Harita Müh. Böl. & Ö.Ö. ve İ.Ö. & Seçmeli & 6. \\
\hline $\begin{array}{l}\text { Taşınmaz Mal Değerlemesi } \\
\text { Uygulaması }\end{array}$ & Afyon Kocatepe Ü., Harita Müh. Böl. & Ö.0̈. & Seçmeli & 7. \\
\hline Taşınmaz Mal Değerlemesi & Konya Teknik Ü., Harita Müh. Böl. & Ö.Ö. & Seçmeli & 7. \\
\hline
\end{tabular}

Lisans programı olarak eğitim veren üniversiteler Tablo 2'de verilmiștir. Tablo 2'ye göre 3 devlet ve 3 vakıf üniversitesinde lisans programı bulunmaktadır. Bunlardan Bandırma 17 Eylül Üniversitesi Gayrimenkul ve Varlık Değerleme lisans programı ile Giresun Üniversitesi Gayrimenkul ve Varlık Değerleme lisans programı açılmış olmasına rağmen henüz eğitime başlamamışlardır. Tablodaki tüm üniversitelerde örgün eğitim verilmektedir. Eğitim dili Yeditepe Üniversitesi Gayrimenkul
Geliştirme ve Yönetimi lisans programında İngilizce iken diğer tüm üniversitelerde Türkçedir. $\mathrm{Bu}$ programların akademik kadroları incelendiğinde Ankara Üniversitesi Gayrimenkul Geliștirme ve Yönetimi Bölümünün akademik kadro sayısı ve çeşitliliği dikkat çekmektedir. Yine Ankara Üniversitesi Gayrimenkul Geliştirme ve Yönetimi Bölümü verilen 56 zorunlu ve 14 seçmeli ders ile dikkat çekmektedir. Diğer üniversitelerde verilen toplam ders sayıları birbirine yakındır.

Tablo 2. Lisans programı kapsamında tașınmaz değerleme eğitimi veren üniversiteler

\begin{tabular}{|c|c|c|c|c|c|c|c|c|}
\hline 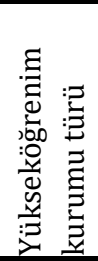 & Lisans programının adı & $\begin{array}{l}\text { Bağlı olduğu } \\
\text { yükseköğrenim kurumu }\end{array}$ & $\begin{array}{l}\text { Aktif/ } \\
\text { Pasif }\end{array}$ & $\begin{array}{l}\text { Örgün } \\
\text { Öğretim } \\
\text { /İkinci } \\
\text { Öğretim }\end{array}$ & $\begin{array}{l}\text { Programı } \\
\text { n Dili } \\
\text { (Türkçe/ } \\
\text { İngilizce) }\end{array}$ & $\begin{array}{l}\text { Ders } \\
\text { Sayıları } \\
\text { (Toplam/ } \\
\text { Zorunlu } \\
\text { /Seçmeli) }\end{array}$ & $\begin{array}{l}\text { Kontenja } \\
\text { n (2018- } \\
2019 \text { yılı) }\end{array}$ & $\begin{array}{l}\text { Öğretim üyesi } \\
\text { dağılımı } \\
\text { (Toplam/Prof } \\
\text {.Dr./Doçent } \\
\text { Dr./Dr. Öğr. } \\
\text { Üy./Öğr. Gör.) }\end{array}$ \\
\hline & $\begin{array}{l}\text { Gayrimenkul } \\
\text { Geliștirme ve Yönetimi } \\
\text { Bölümü }\end{array}$ & $\begin{array}{l}\text { Ankara Ü., Uygulamalı } \\
\text { Bilimler Fakültesi }\end{array}$ & Aktif & $\begin{array}{l}\text { Örgün } \\
\text { Öğretim }\end{array}$ & Türkçe & $70 / 56 / 14$ & 80 & $17 / 6 / 3 / 1 / 7$ \\
\hline 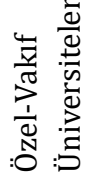 & $\begin{array}{l}\text { Gayrimenkul ve } \\
\text { Gayrimenkul } \\
\text { Geliştirme ve Yönetimi }\end{array}$ & $\begin{array}{l}\text { Yeditepe Ü., } \\
\text { Uygulamalı } \\
\text { Yüksekokulu }\end{array}$ & Aktif & $\begin{array}{l}\text { Örgün } \\
\text { Öğretim }\end{array}$ & İngilizce & $46 / 40 / 6$ & 17 & $5 / 1 / 1 / 3 /-$ \\
\hline
\end{tabular}




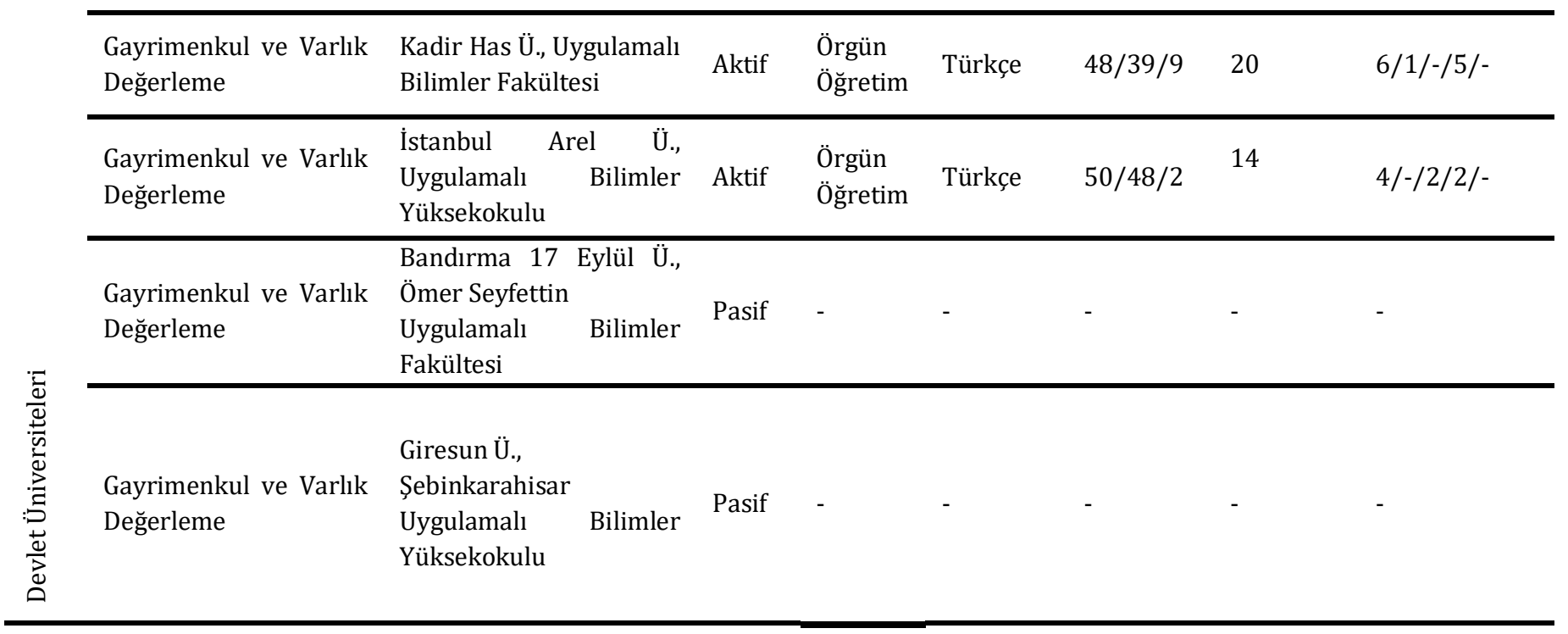

Lisansüstü programı kapsamında tașınmaz değerleme eğitim veren üniversiteler Tablo 3'te verilmiştir. Tablo 3'e göre beş üniversite lisansüstü eğitimi vermektedir. Bunlardan İstanbul Esenyurt Üniversitesi Gayrimenkul Değerlemesi ve
Finansmanı programında örgün öğretim yapılırken, Karadeniz Teknik Üniversitesi Taşınmaz Değerleme ve Geliştirme programında ikinci öğretim yapılmaktadır. Diğer üç üniversitede ise uzaktan eğitim yapılmaktadır.

Tablo 3. Lisansüstü programı kapsamında tașınmaz değerleme eğitim veren üniversiteler

\begin{tabular}{|c|c|c|c|c|c|c|c|}
\hline $\begin{array}{l}\text { Lisansüstü programının } \\
\text { adı }\end{array}$ & $\begin{array}{l}\text { Bağlı olduğu } \\
\text { yükseköğrenim } \\
\text { kurumu }\end{array}$ & $\begin{array}{l}\text { Aktif/ } \\
\text { Pasif }\end{array}$ & $\begin{array}{l}\text { Örgün } \\
\text { Öğgretim/İkinci } \\
\text { Öğretim/Uzakt } \\
\text { an Öğretim }\end{array}$ & $\begin{array}{l}\text { Programı } \\
\text { n Dili } \\
\text { (Türkçe/İ } \\
\text { ngilizce }\end{array}$ & $\begin{array}{l}\text { Ders } \\
\text { Sayıları } \\
\text { (Toplam } \\
\text { /Zorunl } \\
\text { u/Seçm } \\
\text { eli }\end{array}$ & Kontenjan & $\begin{array}{l}\text { Öğretim üyesi } \\
\text { dağılımı } \\
\text { (Toplam/Prof.Dr./ } \\
\text { Doçent Dr./Dr. } \\
\text { Öğr. Üy./Öğr. Gör.) }\end{array}$ \\
\hline $\begin{array}{l}\text { Gayrimenkul Değerlemesi } \\
\text { ve Finansmanı (Tezsiz } \\
\text { Yüksek Lisans) }\end{array}$ & $\begin{array}{l}\text { İstanbul } \\
\text { Esenyurt Ü. }\end{array}$ & Aktif & Örgün Öğretim & Türkçe & $10 / 5 / 5$ & - & $6 / 1 /-/ 5 /-$ \\
\hline $\begin{array}{l}\text { Gayrimenkul Finansmanı } \\
\text { ve Değerleme (Tezsiz } \\
\text { Yüksek Lisans) }\end{array}$ & $\begin{array}{l}\text { İstanbul Okan } \\
\text { Ü. }\end{array}$ & Aktif & Uzaktan Eğitim & Türkçe & $10 / 7 / 3$ & - & $5 / 3 / 1 /-/ 1$ \\
\hline $\begin{array}{l}\text { Taşınmaz Değerleme ve } \\
\text { Geliştirme } \\
\text { (Tezsiz Yüksek Lisans) }\end{array}$ & 19 Mayıs Ü. & Aktif & Uzaktan Eğitim & Türkçe & 11/11/- & 50 & $11 / 7 / 3 / 1 /-$ \\
\hline $\begin{array}{l}\text { Taşınmaz Değerleme ve } \\
\text { Geliştirme } \\
\text { (Tezsiz Yüksek Lisans) }\end{array}$ & $\begin{array}{l}\text { Tekirdağ } \\
\text { Namık Kemal } \\
\text { Ü. } \\
\end{array}$ & Aktif & Uzaktan Eğitim & Türkçe & - & 80 & $15 / 4 / 1 / 10 /-$ \\
\hline $\begin{array}{l}\text { Taşınmaz Değerleme Ve } \\
\text { Geliştirme } \\
\text { (Tezsiz Yüksek Lisans) }\end{array}$ & $\begin{array}{l}\text { Karadeniz } \\
\text { Teknik Ü., Fen } \\
\text { Bilimleri } \\
\text { Enstitüsü, } \\
\end{array}$ & Aktif & İkinci Öğretim & Türkçe & $10 / 5 / 5$ & 60 & $14 / 4 / 6 / 4 /-$ \\
\hline
\end{tabular}

Türkiye'de taşınmaz değerlemesi yapabilmesi için Konut Değerleme Lisansı veya daha geniş kapsamlı Gayrimenkul Değerleme Lisansı alınması şarttır. Bu lisanları alabilmek için SPL tarafından düzenlenen sınavlarda başarılı olmak gerekmektedir (Nişancl, 2005; Erdem, 2017; Çay ve Boz, 2018; Ertaş, 2018; URL-4). Gayrimenkul Değerleme (GD) ve Konut Değerleme (KD) Lisansı sınav konuları ve alt konu başlıkları ile ders, lisans ve lisansüstü düzeyde verilen ders içerikleri Tablo 4, Tablo 5 ve Tablo 6'da karşılaştırılmıştır. Dar kapsamlı Sermaye Piyasası Mevzuatı ve Meslek Kuralları ile Gayrimenkul Değerleme Esasları konu başlıkları her iki lisanslama için ortak konulardır. Tablo 4'te ders düzeyinde taşınmaz değerleme eğitimi veren programlardaki ders içeriklerinin Gayrimenkul Değerleme ve Konut Değerleme Lisansı sınav konuları ve alt konu başlıkları ile ne derecede uyumlu olduğu analiz edilmiştir. Burada, ders adında "Değerleme" ibaresi geçen dersler sadece dikkate alınmıştır. Tek tek incelenen ders içerikleri, lisanslama sınav konuların göre "uyumlu", "kısmen uyumlu" ve "uyumsuz" olarak nitelendirilmiştir. Buna göre tüm lisanslama sınav konularına uyumlu ders içeriği bulunamamıştır. Bunun temel sebebi çok geniş bir kapsamı olan lisanslama sınav konularının tek bir ders içerisinde anlatılmasının mümkün olamamasıdır. Verilen derslerin büyük bir çoğunluğu Gayrimenkul Değerleme Esasları konu başlı̆̆ıyla uyumludur. Gayrimenkul Mevzuatı konu başlığı 
açısından ise bu durum kısmen uyumlu olarak gerçekleşmektedir. Verilen derslerin içeriği, Dar kapsaml Sermaye Piyasası Mevzuatı ve Meslek Kuralları ile Inşaat ve Gayrimenkul Muhasebesi konu başlıkları ile birkaç üniversite (Bunlarda kısmen uyumludur) haricinde uyumsuzdur.

Tablo 5'te Gayrimenkul Değerleme ve Konut Değerleme Lisansı Sınav konuları ve alt konu başlıkları içeriğine göre hazırlanmış; lisans düzeyinde eğitim veren programlardaki zorunlu ve seçmeli ders sayıları verilmiştir. Lisans sınav alt konu bașlıklarını içeren zorunlu ve seçmeli ders sayısı ile ilgili programların sınav konu başlıklarını ne derece kapsadığı belirlenmeye çalışılmıştır. Tablo 5'e göre tüm üniversitelerin lisans programlarında Gayrimenkul Değerleme ve Konut Değerleme Lisansı sınav konuları ve alt konu başlıkları ile ilişkili yeterli sayıda ders verilmektedir. Gayrimenkul Mevzuatı ile Gayrimenkul Değerleme Esasları konuları ve alt konu başlıkları ile ilişkili verilen ders sayısı diğer iki konu başlığına göre çok daha fazladır. "İnşaat ve Gayrimenkul Muhasebesi" ve "Dar kapsaml Sermaye Piyasası Mevzuatı ve Meslek Kuralları" konu başlıklarına ilişkin seçmeli ve zorunlu derslerin sayılarının artırılması bu konuları içeren sınavlardaki başarıyı daha da arttıracaktır.

Tablo 6'da Gayrimenkul Değerleme ve Konut Değerleme Lisansı Sınav konuları ve alt konu başlıkları içeriğine göre hazırlanmış lisansüstü eğitim veren programlardaki zorunlu ve seçmeli ders sayları verilmiştir. Tablo 6'ya göre tüm üniversitelerin lisansüstü programlarında Gayrimenkul Değerleme Esasları ile Gayrimenkul Mevzuatı konu başlıkları ile ilişkili yeterli sayıda ders verilmektedir. Diğer yandan Dar kapsamlı Sermaye Piyasası Mevzuatı ve Meslek Kuralları konu başlığı ile ilişkili dersler sadece üç üniversitede verilmektedir.
Bunlar Okan Üniversitesi, Esenyurt Üniversitesi ve Karadeniz Teknik Üniversitesidir. Inșaat ve Gayrimenkul Muhasebesi konu bașlı̆̆ ile ilișkili olarak Okan üniversitesi hariç diğer dört üniversitede dersler verilmektedir. Bu lisansüstü programların özellikle Dar kapsamlı Sermaye Piyasası Mevzuatı ve Inşaat ve Gayrimenkul Muhasebesi sınav konu başlıklarında daha fazla seçmeli ve zorunlu ders açmaları nitelikli değerleme uzmanı yetiştirilmesine katkı sağlayacaktır.

Lisanslama sınavları; kâğıt ortamında ve elektronik ortamda olmak üzere iki farklı șekilde gerçekleştirilmektedir (URL-2). Tablo 72016 ile 2018 yılları arasında yapılan lisanslama sınavı ile ilişkili istatistiki bilgiler içermektedir (SPL, 2018). Tablo 7'de verilen istatistiki veriler kullanılarak, yıllar bazında konu başlıklarını göre başarı yüzdesi grafiği olușturulmuştur. Şekil 1'deki grafiğe göre Gayrimenkul Değerleme Esasları ile İnşaat ve Gayrimenkul Muhasebesi sinav oturumlarında elde edilen başarı sürekli artarken Dar kapsamlı Sermaye Piyasası Mevzuatı ve Meslek Kuralları ile Gayrimenkul Mevzuatı sinav oturumlarında elde edilen başarı yüzdesi değişkenlik göstermektedir. 2018 yılında elektronik ortamda yapılan sınavda tüm oturumlarda elde edilen bașarı yüzdesi \% 40'ın üzerine çıkmıştır. Kâğıt ortamında yaplan SPL sınavina giren adaylar sinavın tamamına ücret yatırdığı için genellikle 4 oturumu da çözmeye çalıșmaktadır. Bu durum sınav esnasında strese neden olarak adayların başarısını düşürebilmektedir. Elektronik ortamda yapılan sinavda ise adaylar isterse tek oturuma da girip soruları çözebilmektedir. Tek oturuma hazırlanıp sınava girmek daha kolay olduğu için sınavdaki başarı yüzdesi de buna paralel olarak artmaktadır. 
Tablo 4. Ders bazlı taşınmaz değerleme eğitiminin sermaye piyasası lisansı sınav kapsamına göre karşılaștırılması

\begin{tabular}{|c|c|c|c|c|c|}
\hline \multirow[b]{2}{*}{$\begin{array}{l}\text { Dersin adı } \\
\text { (Z: Zorunlu, S: Seçmeli) }\end{array}$} & \multirow[b]{2}{*}{$\begin{array}{l}\text { Dersin verildiği yülsseköğrenim } \\
\text { kurumu }\end{array}$} & \multicolumn{4}{|c|}{$\begin{array}{l}\text { Gayrimenkul Değerleme (GD) ve Konut Değerleme (KD) Lisansi } \\
\text { Sinav Konuları }\end{array}$} \\
\hline & & $\begin{array}{c}\text { Dar kapsamlı } \\
\text { Sermaye Piyasası } \\
\text { Mevzuatı ve } \\
\text { Meslek Kuralları } \\
\text { (GD ve KD için) }\end{array}$ & $\begin{array}{c}\text { Gayrimenluıl } \\
\text { Değerleme } \\
\text { Esasları (GD } \\
\text { ve } \mathrm{KD} \text { için) }\end{array}$ & $\begin{array}{l}\text { İnşaat ve } \\
\text { Gayrimenkul } \\
\text { Muhasebesi } \\
\text { (GD için) }\end{array}$ & $\begin{array}{c}\text { Gayrimenku } \\
1 \text { Mevzuat1 } \\
\text { (GD için) }\end{array}$ \\
\hline $\begin{array}{lcl}\text { CBS ile } & \text { Taşınmaz } \\
\text { Değerlemesi (S) } & \end{array}$ & Alksaray Ü.,Harita Müh. Böl. & - Uyumsuz & -Uyumlu & - Uyumsuz & $\begin{array}{l}\text {-Kısmen } \\
\text { uyumlu }\end{array}$ \\
\hline Gayrimenkul Değerleme (Z) & $\begin{array}{l}\text { Çanalkkale } 18 \text { Mart Ü., Harita Müh. } \\
\text { Bö1. }\end{array}$ & - Uyumsuz & -Uyumlu & - Uyumsuz & -Uyumlu \\
\hline Gayrimenkul Deǧerleme (Z) & Erciyes Ü., Harita Müh. Böl & - Uyumsuz & -Uyumlu & - Uyumsuz & $\begin{array}{l}\text {-Kismen } \\
\text { uyumlu }\end{array}$ \\
\hline $\begin{array}{l}\text { Gayrimenkul Değerleme } \\
\text { Uygulamaları (S) }\end{array}$ & Erciyes Ü., Harita Müh. Böl & - Uyumsuz & -Uyumlu & - Uyumsuz & - Uyumsuz \\
\hline $\begin{array}{l}\text { SPL Dar Kapsamil Sermaye } \\
\text { Piyasas1 Mevzuat1 ( }(\text { ) }\end{array}$ & Erciyes Ü., Harita Müh. Böl & - Uyumsuz & - Uyumsuz & - Uyumsuz & -Uyumlu \\
\hline $\begin{array}{l}\text { SPL Gayrimenkul } \\
\text { Değerleme Esasları (S) }\end{array}$ & Erciyes Ü., Harita Müh. Böl & - Kismen uyumlu & -Uyumlu & - Uyumsuz & $\begin{array}{l}\text {-Kismen } \\
\text { uyumlu }\end{array}$ \\
\hline $\begin{array}{l}\text { Taşınmaz Geliștirmesi ve } \\
\text { Değerlemesi }(\mathrm{Z})\end{array}$ & Okan Ü., Geomatik Müh. Böl. & - Kismen uyumlu & -Uyumlu & $\begin{array}{l}- \text { Kismen } \\
\text { uyumlu }\end{array}$ & $\begin{array}{l}\text {-Kismen } \\
\text { uyumlu }\end{array}$ \\
\hline $\begin{array}{l}\text { Taşınmazların } \\
\text { Değerlendirilmesi (S) }\end{array}$ & Gümüş̧hane Ü.,Harita Müh. Böl. & - Uyumsuz & -Uyumlu & - Uyumsuz & -Uyumlu \\
\hline Taşınmaz Değerlemesi (S) & $\begin{array}{l}\text { Necmettin Erbakan Ü., Harita Müh. } \\
\text { Böl. }\end{array}$ & - Uyumsuz & -Uyumlu & - Uyumsuz & $\begin{array}{l}\text {-Kismen } \\
\text { uyumlu }\end{array}$ \\
\hline Taşınmaz Değerlemesi (S) & $\begin{array}{l}\text { Niğde Ömer Halisdemir Ü., } \\
\text { Harita Müh, Böl. }\end{array}$ & - Kismen uyumlu & -Uyumlu & - Uyumsuz & $\begin{array}{l}\text {-Kismen } \\
\text { uyumlu }\end{array}$ \\
\hline Taşınmaz Değerlemesi (Z) & Hacettepe Ü., Geomatik Müh. Böl. & - Uyumsuz & -Uyumlu & - Uyumsuz & $\begin{array}{l}\text {-Kismen } \\
\text { uyumlu }\end{array}$ \\
\hline Taşınmaz Değerlemesi $(\mathrm{S})$ & Cumhuriyet Ü., Geomatik Müh. Bö1. & - Uyumsuz & -Uyumlu & - Uyumsuz & -Uyumlu \\
\hline Taşınmaz Değerlemesi (S) & $\begin{array}{l}\text { Osmaniye Korkut Ata Ü., } \\
\text { Harita Müh. Böl. }\end{array}$ & - Uyumsuz & -Uyumlu & - Uyumsuz & -Uyumlu \\
\hline Taşınmaz Değerlemesi (Z) & Artvin Çoruh Ü., Harita Müh. Böl. & - Uyumsuz & -Uyumlu & - Uyumsuz & -Uyumlu \\
\hline Taşınmaz Değerlemesi (Z) & Yıldız Teknik Ü., Harita Müh. Bö1. & - Kismen uyumlu & -Uyumlu & - Uyumsuz & $\begin{array}{l}\text {-Kismen } \\
\text { uyumlu }\end{array}$ \\
\hline Taşınmaz Değerlemesi (Z) & $\begin{array}{l}\text { İstanbul Telnik Ü. Geomatik Müh. } \\
\text { Böl. }\end{array}$ & - Uyumsuz & -Uyumlu & - Uyumsuz & $\begin{array}{l}-\mathrm{K} \text { ismen } \\
\text { uyumlu }\end{array}$ \\
\hline Taşınmaz Değerlemesi $(Z)$ & Karadeniz Telnik Ü.,Harita Müh.Böl. & - Uyumsuz & -Uyumlu & - Uyumsuz & -Uyumlu \\
\hline Taşınmaz Değerlemesi (Z) & Kocaeli Ü., Harita Müh. Böl. & - Uyumsuz & -Uyumlu & - Uyumsuz & $\begin{array}{l}\text {-Kismen } \\
\text { uyumlu }\end{array}$ \\
\hline Taşınmaz Değerlemesi (S) & Bülent Ecevit Ü., Geomatik Müh. Böl. & - Uyumsuz & -Uyumlu & - Uyumsuz & $\begin{array}{l}\text {-Kismen } \\
\text { uyumlu }\end{array}$ \\
\hline $\begin{array}{l}\text { Taşınmaz Mal Değerlemesi } \\
\text { (Z) }\end{array}$ & Harran Ü., Harita Müh.Böl. & - Kismen uyumlu & -Uyumlu & - Uyumsuz & $\begin{array}{l}\text {-Kismen } \\
\text { uyumlu }\end{array}$ \\
\hline $\begin{array}{l}\text { Taşınmaz Mal Değerlemesi } \\
\text { (S) }\end{array}$ & Konya Teknik Ü., Harita Müh. Bö1. & - Uyumsuz & -Uyumlu & - Uyumsuz & $\begin{array}{l}\text {-Kismen } \\
\text { uyumlu }\end{array}$ \\
\hline $\begin{array}{l}\text { Taşınmaz Mal Değerlemesi } \\
\text { Uygulaması (S) }\end{array}$ & Harran Ü., Harita Müh. Böl. & - Uyumsuz & -Uyumlu & $\begin{array}{l}- \text { Kismen } \\
\text { uyumlu }\end{array}$ & - Uyumsuz \\
\hline $\begin{array}{l}\text { Taşınmaz Mal Değerlemesi } \\
\text { Uygulaması (S) }\end{array}$ & Afyon Kocatepe Ü., Harita Müh. Böl. & - Uyumsuz & -Uyumlu & $\begin{array}{l}- \text { Kismen } \\
\text { uyumlu }\end{array}$ & $\begin{array}{l}-\mathrm{K} \text { ismen } \\
\text { uyumlu }\end{array}$ \\
\hline
\end{tabular}


Tablo 5. Lisans düzeyinde taşınmaz değerleme eğitiminin sermaye piyasası lisansı sınav kapsamına göre karşılaştırılması

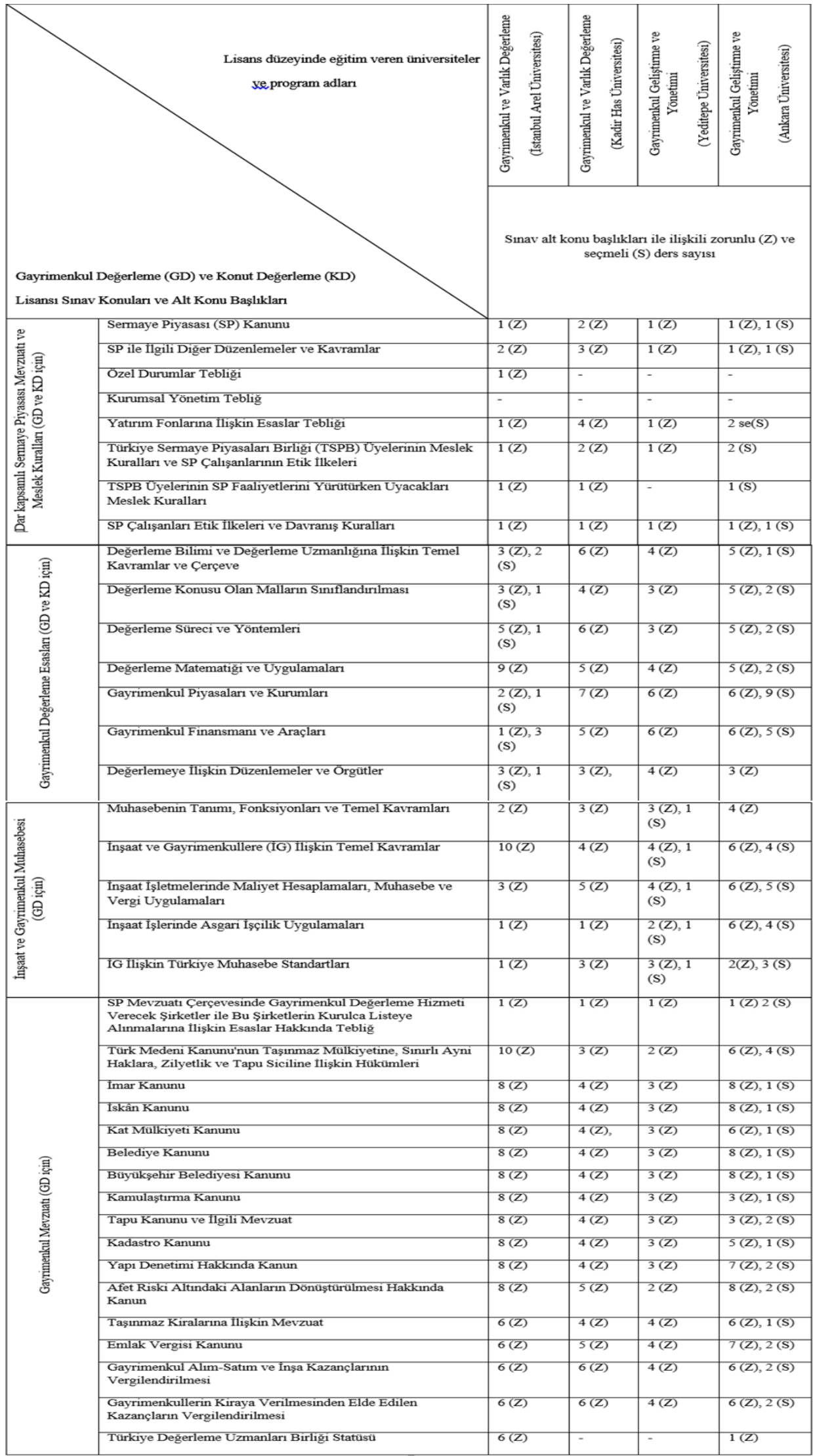


Tablo 6. Lisansüstü taşınmaz değerleme eğitiminin sermaye piyasası lisansı sınav kapsamına göre karşılaștırılması

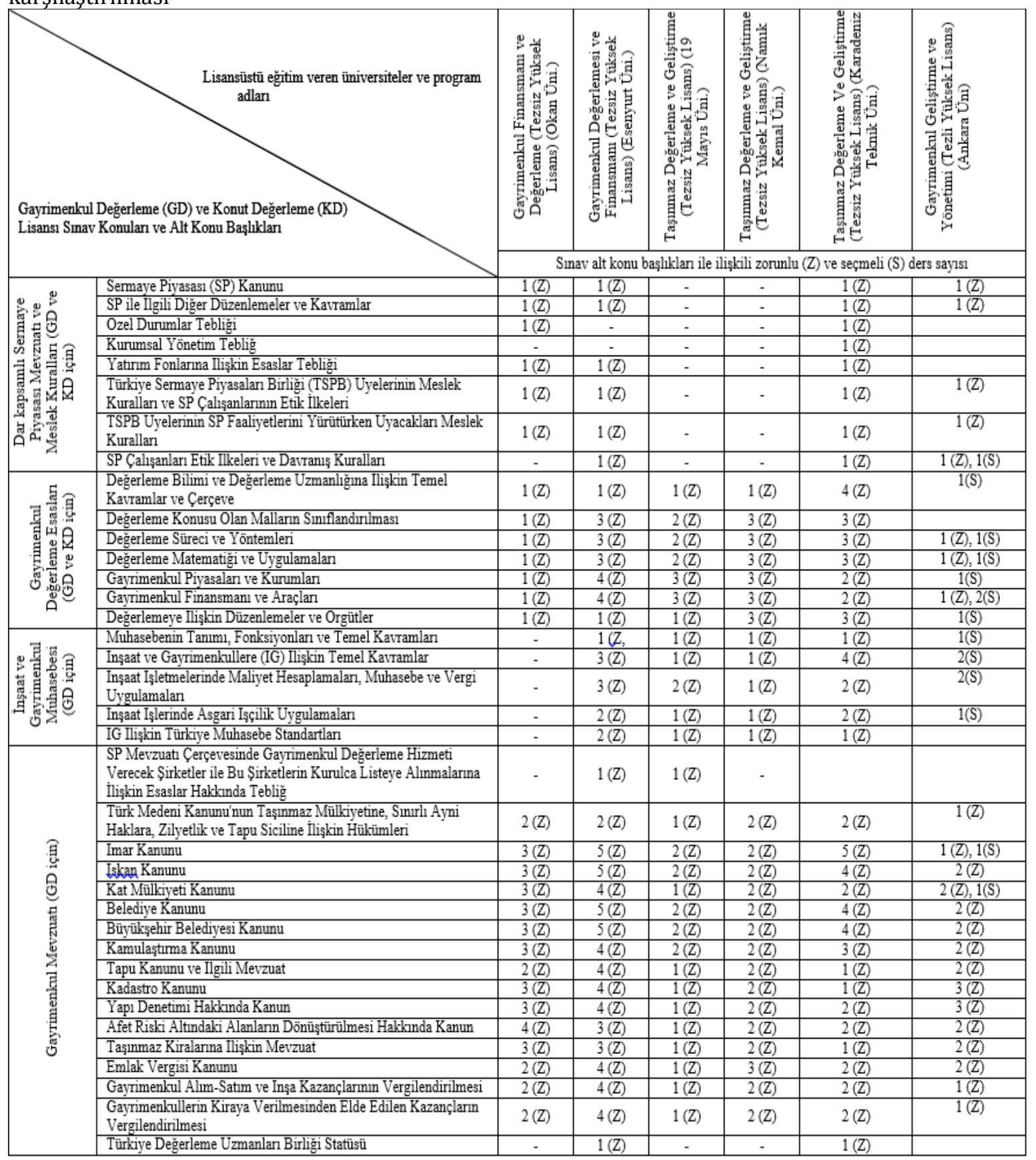


Tablo 7. 2016 yılından itibaren yapılan sermaye piyasası lisanslama (SPL) sınavına ilişki istatistiki bilgiler

\begin{tabular}{|c|c|c|c|c|c|c|c|c|c|c|c|c|}
\hline \multirow{3}{*}{$\begin{array}{l} \\
\text { Gayrimenkul } \\
\text { Değerleme } \\
\text { (GD) ve Konut } \\
\text { Değerleme } \\
\text { (KD) Lisansı } \\
\text { Sinav Konuları }\end{array}$} & \multicolumn{12}{|c|}{ Sermaye Piyasası Lisanslama (SPL) Sinav Yilları } \\
\hline & \multicolumn{3}{|c|}{2016} & \multicolumn{3}{|c|}{2017} & \multicolumn{3}{|c|}{2018} & \multicolumn{3}{|c|}{2018 e-LS } \\
\hline & $\begin{array}{c}\text { Katilim } \\
\text { Sayısı }\end{array}$ & $\begin{array}{c}50 \text { ve } \\
50+ \\
\text { Puan } \\
\text { Alan } \\
\text { Kişi } \\
\text { Sayısı }\end{array}$ & $\begin{array}{c}\text { Başarı } \\
\text { Oranı } \\
(\%)\end{array}$ & $\begin{array}{l}\text { Katilım } \\
\text { Sayıs }\end{array}$ & $\begin{array}{c}50 \text { ve } \\
50+ \\
\text { Puan } \\
\text { Alan } \\
\text { Kişi } \\
\text { Sayıs }\end{array}$ & $\begin{array}{c}\text { Başarı } \\
\text { Oranı } \\
(\%)\end{array}$ & $\begin{array}{c}\text { Katilım } \\
\text { SayısI }\end{array}$ & $\begin{array}{c}50 \text { ve } \\
50+ \\
\text { Puan } \\
\text { Alan } \\
\text { Kişi } \\
\text { Sayıs }\end{array}$ & $\begin{array}{c}\text { Başarı } \\
\text { Oranı } \\
(\%)\end{array}$ & $\begin{array}{c}\text { Katilım } \\
\text { Sayıs }\end{array}$ & $\begin{array}{c}50 \text { ve } \\
50+ \\
\text { Puan } \\
\text { Alan } \\
\text { Kişi } \\
\text { Sayısı }\end{array}$ & $\begin{array}{c}\text { Başarı } \\
\text { Oranı } \\
(\%)\end{array}$ \\
\hline $\begin{array}{l}\text { Dar } \\
\text { kapsamlı } \\
\text { Sermaye } \\
\text { Piyasası } \\
\text { Mevzuatı ve } \\
\text { Meslek } \\
\text { Kuralları (GD } \\
\text { ve KD için) }\end{array}$ & 32.647 & 10.564 & $\% 32$ & 33.033 & 6.606 & $\% 20$ & 11.274 & 4.284 & $\% 38$ & 4.691 & 1970 & $\% 42$ \\
\hline $\begin{array}{l}\text { Gayrimenkul } \\
\text { Değerleme } \\
\text { Esasları (GD } \\
\text { ve KD için) }\end{array}$ & 10.912 & 1.182 & $\% 11$ & 16.735 & 3.849 & $\% 23$ & 4.318 & 1.641 & $\% 38$ & 3.203 & 1602 & $\% 51$ \\
\hline $\begin{array}{l}\text { İnşaat ve } \\
\text { Gayrimenkul } \\
\text { Muhasebesi } \\
\text { (GD için) }\end{array}$ & 7.226 & 2.426 & $\% 34$ & 13.716 & 5.624 & $\% 41$ & 3.736 & 1.681 & $\% 45$ & 2.302 & 1.151 & $\% 51$ \\
\hline $\begin{array}{l}\text { Gayrimenkul } \\
\text { Mevzuatı (GD } \\
\text { icin) }\end{array}$ & 9.545 & 1.976 & $\% 26$ & 15.361 & 2.765 & $\% 18$ & 4.427 & 531 & $\% 12$ & 3.811 & 1.753 & $\% 46$ \\
\hline
\end{tabular}

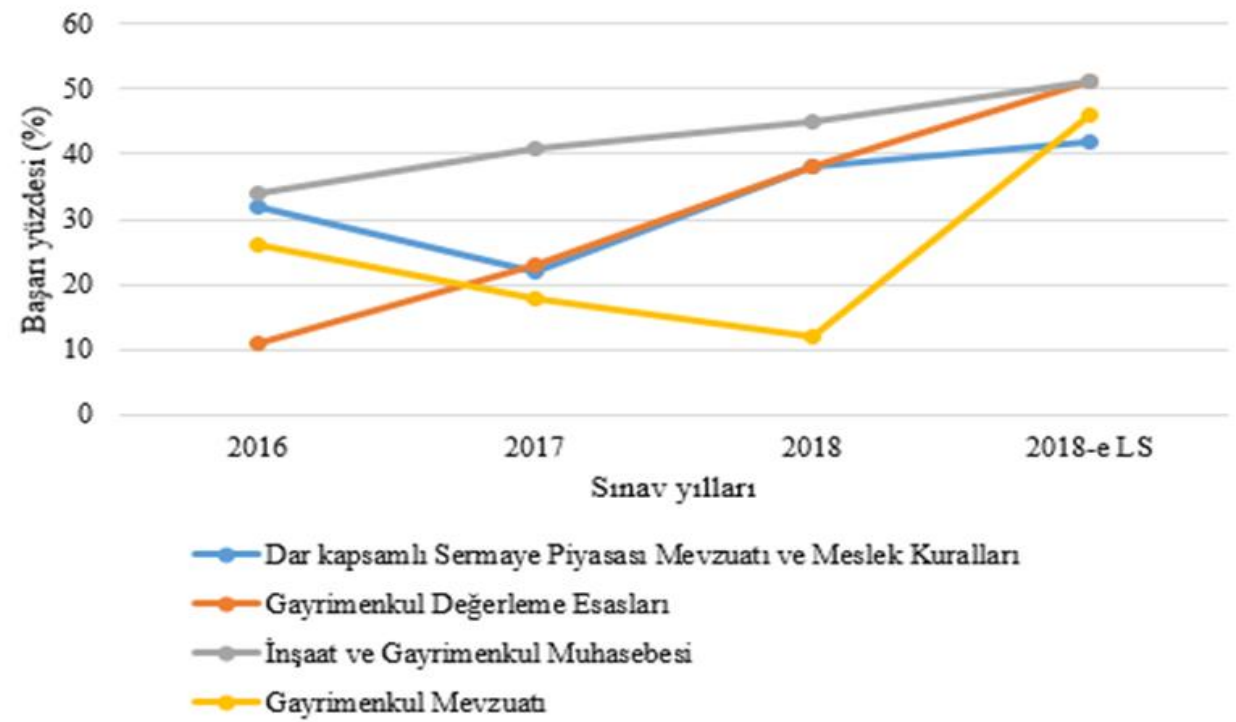

Şekil 1. Yıllara göre sermaye piyasası lisanslama (SPL) sınavı başarı yüzdesi

\section{TARTIŞMA}

Sürdürülebilir bir taşınmaz değerleme yapısı oluşturabilmek için gerekli olan en önemli aktörlerden biri taşınmaz değerleme uzmanıdır. Taşınmaz değerleme uzmanının yetişmesinde güncel, sektörün ihtiyaçlarını dikkate alan, uluslararası gelişme ve standartlara uygun olarak hazırlanan taşınmaz değerleme eğitiminin katkısı oldukça büyüktür (McParland vd., 2002). Taşınmaz değerlemenin kullanılmaya başlandığı dönemlerde bu alanda ihtiyaç duyulan eğitim daha çok harita mühendisliği bölümü bünyesinde verilen taşınmaz değerleme dersi ile karşılanmaktaydı. Ders bazında verilen taşınmaz değerleme eğitimi oldukça yetersiz kalmaktadır. Bunun temel sebebi taşınmaz değerlemenin tek bir derste anlatılamayacak kadar çok geniş bir içeriğe sahip olmasıdır. Ders bazında 
eğitim alan kişiler taşınmaz değerleme sektörünün ihtiyaçlarını karşılamada yetersiz kalmıştır. Taşınmaz değerlemenin öneminin ve kulanım alanının artmasıyla birlikte son yıllarda üniversitelerde lisans ve lisansüstü düzeyde eğitim veren yeni programlar açılmaya başlamıştır. Bu programlar kapsamında verilen derslerin içeriğinin, SPL lisansı sınavına ve sektörün beklentilerine daha uygun olduğu gözlemlenmiștir. Fakat sektörün sürekli gelişmesiyle birlikte yeni ders içeriklerine ihtiyaç duyulmaktadır. Bu bağlamda bu ihtiyacı dikkate alarak ders içerikleri sürekli güncellenmesi sektörün ihtiyacı olan donanım ve eğitime sahip olan mezunların yetiştirilmesinde oldukça önemlidir. Güncel ve sektörün ihtiyacına cevap veren ders içerikleri ancak nitelikli akademik kadro tarafından verilebilir. Taşınmaz değerleme yoğun olarak harita mühendisliği, inşaat harita mühendisliği, mimarlık, şehir ve bölge planlama, ekonomi ve finans alanları ile ilişkilidir. $\mathrm{Bu}$ nedenle ideal bir taşınmaz değerleme eğitimi verebilmek için bu alanlarda uzman akademik kadronun oluşturulması gerekmektedir. Lisans ve lisansüstü düzeyde eğitim veren üniversitelerin akademik kadroları incelendiğinde genel olarak yetersiz olduğu söylenebilir. Bazı lisans programların akademik kadrosunda taşınmaz sektörü ile alakası olmayan alanda uzmanlaşmış kişiler bulunmaktadır. Örneğin kimya mühendisliği, tekstil mühendisliği, bilgi yönetim sistemi gibi alanlarda uzman kişiler değerleme eğitimi vermektedir. $\mathrm{Bu}$ durum verilen taşınmaz değerleme eğitimini olumsuz etkilemektedir. Taşınmaz değerleme eğitimi için asıl ihtiyaç duyulan Harita Mühendisliği, Inşat Mühendisliği, Şehir ve Bölge Planlama, Iktisat gibi bölümlerde ise öğretim üyesi eksiği bulunmaktadır. Taşınmaz değerlemeye uzmanı adayının, ya da lisans almış uzmanın eğitimi açısından konulmuş koşul bulunmamaktadır (Köktürk, 2009). Sınavdan yeterli puanı almak ve gerekli mesleki tecrübe şartını yerine getirmek şuan ki yerine getirilmesi gereken şartlardır. Bu açıdan bakıldığında 4 yıllık yüksekokul mezunu herkes için lisans alma yolu açıtır. Dünyadaki uygulamalarda ise taşınmaz değerlemeyle ilişkili 4 yıllık okul mezunu olma şartı aranmaktadır (Köktürk, 2009). Bu nedenle ülkemizde lisans almak için taşınmaz değerleme konusunda alınmış bir eğitim koşulu yerinde olacaktır.

SPL sınavının kâğıt ortamına ek olarak elektronik ortamda ve sıklıkla yapılması olumlu bir gelişmedir. Böylelikle lisans alma süreci daha da kısalacaktır. Lisans alma başarısı gösteren kişilerin bu hakkını kullanabilmesi için tecrübe şartı gereklidir. Bu süre Konut Değerleme Uzmanları için en az 1 yıl, Gayrimenkul Değerleme Uzmanları için en az 3 yıldır (URL-3). Bu kişiler Uzman Yardımcısı sıfatıyla değerleme şirketlerinde imza yetkisi olmaksızın istenilen sürelerde değerleme çalışmaları yaparak asgari tecrübe şartını yerine getirmiş olurlar.
Konut değerlemede sadece konutların değeri belirlenmektedir. Gayrimenkul değerleme de ise konut değerlemeye ek olarak ilgili konuta ilişkin hak ve faydalarda değerlenmektedir. Dolayısıyla gayrimenkul değerleme sınav konuları konut değerleme sınav konularını da içine alan bir yapıda hazırlanmıştır. 2018 yılında yapılan toplam değerleme raporlar içinde konut nitelikli taşınmazlara ait raporlar \% 67'lik bir paya sahiptir (TDUB, 2019). Bu veri konut değerlemenin gayrimenkul değerleme içerisinde önemli bir yere sahip olduğunu göstermektedir.

2017 yılında 1.159 .568 adet gayrimenkul değerleme raporu hazırlanmışken, 2018 ylında 867.546 adet rapor hazırlanmıştır. 2018 yılındaki Toplam 867.546 raporda 1.843 .253 bağımsız taşınmaz değerlemesi yapılmıştır. Bu taşınmazların 921.582 adedi konuttur. Konutun toplam taşınmazlar içindeki oranı \% 50'dir. Konutu \%9 ile dükkan, \% 7 ile tarla, \% 6 ile arsa ve \% 5 ile ofis, $\% 1$ ile fabrika ve \% 1 ile imalathane nitelikli taşınmazlar takip etmektedir (TDUB, 2019). Bunların dışındaki diğer taşınmazların oranı ise \% 21'dir. Konut içerikli değerleme raporunun önemli bir yüzdeye sahiptir. $\mathrm{Bu}$ nedenle "Gayrimenkul Değerleme Esasları" ve "Gayrimenkul Mevzuatı" sinav alt konuları bu değerleme türü için oldukça önemlidir. Herhangi bir 4 yıllık Yükseköğrenim programı mezunu olan kişi sınavda başarılı olması durumunda gayrimenkul değerleme lisansı almaya hak kazanabilmektedir. Benzer şekilde 2 yıllık Yükseköğrenim programı mezunu olan kişide sınavda başarılı olması durumunda konut değerleme lisansı almaya hak kazanabilmektedir.

Sinavda başarılı olma kriteri her bir sınav oturumu için 50 puan ve toplamda 4 oturumun ortalaması olarak en az 60 puan almaktır. Dolayısıyla bazı oturumlarda alınan 90, 100 puan gibi yüksek puanlar sayesinde diğer oturumlardan daha düşük (en az 50 puan) alsa da aday başarılı sayılmaktadır. $\mathrm{Bu}$ durum adayın düşük aldığı sınav oturum konularına yeterince hakim olmadan lisans verilmesine sebep olmaktadır. Bu şekilde lisans almaya hak kazanmış adaylar değerleme raporu hazırlarken zorlanabilmektedir. Gayrimenkul ve varlık değerleme bölümünden mezun olmayan mühendislik, şehir bölge planlama, İIBF mezunu lisans sahibi kișiler genelde bu gruba girmektedir. Bu kişilere ek kriterler getirilmesi veya ilgili alanda yüksek lisans yaptırılması daha nitelikli değerleme uzmanı yetiştirilmesine katkı sunacaktır.

Gayrimenkul Değerleme ve Konut Değerleme Lisansı sınavlarının alt konu başlıklarına göre elde edilen başarı yüzdesi \% 50 ve daha altı şeklinde gerçekleşmiştir (Bakınız Şekil 1). Bu durum sınav konuları ile üniversitelerde verilen değerleme eğitiminin birbiriyle tam uyuşmadığını göstermektedir. $\mathrm{Bu}$ nedenle sınav konuları ile değerleme eğitimi içeriğinin birlikte oluşturulması gerekmektedir. Özellikle gayrimenkul mevzuatı ile ilgili bölümde sorulan soruların adayların 
cevaplayabileceği düzeyde hazırlanması bu bölümdeki bașarı yüzdesini artıracaktır.

6754 sayll Bilirkişilik Kanununun 39'uncu maddesi ile 2942 sayll Kanunun 15'inci maddesinde yapılan değişikliğe göre Kamulaştırma davalarında SPL lisanslı değerleme uzmanı haricinde taşınmaz değerleme ve geliştirme alanında yüksek lisans veya doktora yapmış kişiler bilirkişi olarak atanabilmektedir. Bu yasal ifadeye göre taşınmaz değerleme ve geliştirme alanında yüksek lisans veya doktora yapmış kişiler değerleme lisansına sahip kişiler ile eş tutulmuştur. Bu bakımdan oldukça faydalı bir değişiklik olmuştur. Benzer şekilde, diğer yasalarda ve değerlemeye ilişskin mevzuatta da değişik yapılmalı ve bu gibi kişilerin bilgi birikimlerinden faydalanmalıdır.

90 'lı yılların sonuna doğru ülkemize sermaye girişi öncelikli olarak taşınmazlar üzerinden sağlanmıştır (Ertaş, 2015). Bu gelişmenin etkisiyle taşınmazların değer ile ilgili özelliklerinin güvenilir, gerçek zamanlı ve doğru bir șekilde kaydedilme ihtiyacı ortaya çıkmıştır. Bu ihtiyacı gidermek için tüm 4 yıllık lisans mezunu kişilerin sınavda başarılı olmak kaydı ile değerleme lisansı almasının önü açılmıștır. 0 dönemde ihtiyaç giderilse de lisans eğitimi ilgili alanda olmayan bu kişilerin değerleme konusunda yetersiz kaldığı görülmüştür. Günümüzde ise gayrimenkul değerleme ve geliştirme alanında verilen lisans eğitimi ile alanında daha nitelikli değerleme uzmanı yetiştirilmesi mümkün olmuştur. Bu bakımdan değerleme lisansı almak için gerekli şartlardan biri olan 4 yllık yükseköğrenim mezunu kriterine bir sınırlama getirilmesi uygun olacaktır.

\section{SONUÇLAR ve ÖNERÍLER}

Taşınmaz değerlemesi, bilimsel yöntemlere dayalı, doğru ve tarafsız olarak yapılması gereken bir alandır. Ayrıca, içerdiği hukuki, ekonomik, yapı bilgisi gibi konular bakımından birçok meslek ile iç içedir. $\mathrm{Bu}$ nedenle karşılaştırma, hesaplama yapabilme, rapor hazırlama bilgi ve becerilere sahip olunmasını gerektiren bir meslek dalıdır. $\mathrm{Bu}$ yeterliliklerin taşınmaz değerleme sektöründe faaliyet gösterecek kişilere kazandırılabilmesi için güncel, yeterli, ulusal ve uluslararası akreditasyon ilkeleri ve ölçütleri ile uyumlu bir eğitim verilmesi şarttır. Tașınmaz değerleme uzmanının; yoğun bir haritacılık ve istatistik bilgisi yanında tașınmaz değerleme mevzuatı, işletme ekonomisi, şehir ve bölge planlama, genel finans ve yerel yönetimler konuları hakkında da temel bilgiye sahip olması gerekmektedir. $\mathrm{Bu}$ nedenle disiplinler arası bir yüksek lisans eğitimi ile gerekli bilgi ve beceriler ilgili kişilere aktarılabilir. Taşınmaz değerleme uzmanlığı, sadece kağıt üzerinde öğrenilebilecek bir meslek değil, saha tecrübesi gerektiren, çok sayıda faktörlerin dikkate alınmasını zorunlu kılan özel bir uzmanlık alanıdır. Fakat gayrimenkul ve varlık değerleme kapsamında verilen eğitim herhangi bir mühendislik eğitimine karşıllk gelmemekle birlikte mezunlarına doğrudan bir uzmanlıkta sağlamamaktadır. Bu bağlamda lisansüstü düzeyde uzaktan ve tezsiz eğitim șeklinde verilen eğitim içerikleri revize edilmelidir. Bu çerçevede aşağıda taşınmaz değerleme eğitimi ile SPL lisanslama sınavına ilişkin çeşitli önerilerde bulunulmuştur:

- Şekil 1'deki grafiğe göre 2018 yılında yapılmaya başlanan elektronik sınav ile başarı yüzdesi daha da artmıștır. Zaman içerisinde kağıt formatında yapılan sinavların tamamen kaldırılıp yerine esinav yapılması faydalı olacaktır.

- Son yıllarda yapılan sınavlarda başarı yüzdesi en fazla \% 51 (Bakınız Şekil 1) olarak gerçekleşmiştir. Ders, lisans ve lisansüstü düzeyde eğitim veren programların SPL lisans sinaviyla yeterince uyumlu olmaması (Bakınız Tablo 4, 5 ve 6) bu başarı yüzdesinin yükselmesine engel olmuştur. Başarı yüzdesinin daha da arttırılması için sınav içeriğine uygun olarak dersler revize edilmelidir.

- Lisans almaya hak kazınmış değerleme uzmanlarının değerleme faaliyetlerinde daha başarılı olabilmesi için sektörün ihtiyacına yönelik belirlenecek yeni dersler lisans programlarına eklenmelidir.

- Bazı bölümlerde taşınmaz değerlemeye ilişkin dersler verilmektedir. Verilen derslerin sayısı taşınmaz değerlemenin geniş kapsamlı bir olmasından dolayı yetersiz kalmaktadır. Bu nedenle özellikle ders bazında taşınmaz değerleme eğitimi veren bölümlerde ders sayısı arttırılmalıdır.

- Taşınmaz değerleme tek bir ders kapsamında anlatılamayacak kadar geniş kapsamlı bir alandır. Bu bağlamda taşınmaz değerlemenin bütün boyutlarını ile ilgili eğitimin verildiği lisans düzeyinde programlara ihtiyaç duyulmaktadır. Var olan lisans programlarına ek olarak lisans programları açılmalıdır.

- Faal olarak taşınmaz değerleme eğitimi veren bölümlerin akademik kadro sayısı ve çeşitliliği yetersiz kalmaktadır. Özellikle Harita Mühendisliği, İnşat Mühendisliği, Şehir ve Bölge Planlama, İktisat gibi bölümlerde yetişmiş öğretim üyelerine ihtiyaç vardır. $\mathrm{Bu}$ bağlamda taşınmaz değerleme konusunda uzman ve tecrübesi olan akademik kadro oluşturulmalıdır.

- Türkiye genelinde 5 üniversitede (Bakınız Tablo 3) taşınmaz değerlemeye iliş̧in tezsiz yüksek lisans yapılmaktadır. Taşınmaz değerlemeye ilişkin henüz bir doktor programı açılmamıştır. Ancak amacı bu okullara akademisyen yetiştirmek olan lisansüstü programların halen sayıca az olması taşınmaz değerleme eğitimi kadrolarındaki yetersizliğini açıklayan bir 
göstergedir. Ayrıca akademik kadro yetiştirilebilmesi için tezli lisansüstü eğitim verilmesi şarttır. Bu bağlamda özellikle tezsiz yüksek lisans programları tezli yüksek lisans programlarına dönüştürülmeli ve doktora programları açilmalıdır.

- Ders, lisans ve lisansüstü düzeyde tașınmaz değerleme eğitim-öğretim veren programların, mesleki odalar, ulusal ve uluslararası kurumlarla ilișkisi kurulmalı ve bu kurumların tecrübelerinden faydalanması sağlanmalıdır.

- Taşınmaz değerleme sektörü sürekli gelişen ve kendini güncelleyen bir alandır. $\mathrm{Bu}$ alanda faaliyet gösteren uzman kişilerin bu değişim takip etmeleri oldukça önemlidir. $\mathrm{Bu}$ nedenle, hizmet içi eğitim, ileri seviye eğitim, güncelleme eğitimleri lisansın sürmesinin koşulları olarak zorunlu tutulmalıdır.

- Taşınmaz değerleme eğitiminde kalite ve uluslararası akreditasyon kavramları önem kazanmaktadır. Bu bağlamda uluslararası değerleme kurumları ile uyumlu ulusal akreditasyon ilkeleri ve ölçütleri belirlenmelidir. Bu duruma bağlı olarak var olan bölümlerin eğitim-öğretim kaliteleri ölçülerek eksiklikleri ve ihtiyaçları belirlenmeli ve bunların giderilmesi sağlanmalıdır.

\section{KAYNAKÇA}

Açlar, A., Demir, H., ve Çağdaş, V. (2003). Taşınmaz değerleme uzmanlığı ve jeodezi ve fotogrametri (harita) mühendisliği, HKMO Jeodezi, Jeoinformasyon ve Arazi Yönetimi Dergisi, 88, 1520.

Büyükkaracığan, N., Altınıșık, İ., ve Uzun, H. (2017). Türkiye'de Gayrimenkul Değerleme Çalışmalarında Karşılaşılan Sorunlar Ve Çözüm Önerileri, Selçuk Üniversitesi Sosyal Ve Teknik Araștırmalar Dergisi, 14,77-91.

Çay, T., ve Boz, Y. (2018). Gayrimenkul Değerleme Uzmanlığı Yeterlikleri Açısından Gelişmiş Ülkeler ile Türkiye'nin Karşılaştırılması, $A K \ddot{U}$ FEMÜBID 18, 959-971.

Erdem, N. (2017). Türkiye İçin Bir Taşınmaz Değerleme Sistemi Yaklaşımı, Geomatik Dergisi, 2(3), p.18-36.

Erdem, N. (2018a). Türkiye Taşınmaz Değerleme Sisteminin Yeniden Yapılandırılmasına Yönelik Bilimsel Çalışma Ve Öneriler Üzerine Bir Değerlendirme, Ömer Halisdemir Üniversitesi Mühendislik Bilimleri Dergisi, Cilt 7, Sayı 1, 159170.
Erdem, N., (2018b). Türkiye'de Taşınmaz Değerleme Alanında Yapılan Lisansüstü Tezlerinin İçerik Analizi, Academic Platform-Journal of Engineering and Science, Cilt 6, Sayı 1,112-126.

Ertaş, M. (2015). Real Estate Valuation Training In Turkey, Proceedings of the World Cadastre Summit 2015, Istanbul, p. 523-533.

Hışır, M. (2009). Türkiye'de Taşınmaz Değerleme ve Harita Mühendisliği, TMMOB Harita ve Kadastro Mühendisleri Odası, 12. Türkiye Harita Bilimsel ve Teknik Kurultayı 11-15 Mayıs 2009, Ankara

HKMO, (2012). Arazi Yönetiminde Taşınmaz Değerleme ve Kadastro Sempozyumu Sonuç Bildirgesi.

Köktürk, E. (2009). Taşınmaz Değerleme: Durum Saptaması Ve Yönelimler, 12. Türkiye Harita Bilimsel ve Teknik Kurultayı, Ankara.

Köktürk, E., Çelik, R.N., Özlüdemir, M.T., ve Kılıç, G.. (2005). Harita Sektöründe Eğitim-Öğretim Sorununun Boyutları ve Çözüm Önerileri, 10. Türkiye Harita Bilimsel ve Teknik Kurultayı, Ankara.

McParland, C., Adair, A., ve McGreal, S. (2002) "Valuation standards: A comparison of four European countries", Journal of Property Investment \& Finance, Vol. 20 Issue: 2, pp.127141 , https://doi.org/10.1108/1463578021042002 5

Nişancl, R. (2005). CBS ile Nominal Değerleme Yöntemine Dayalı Piksel Tabanlı Kentsel Taşınmaz Değer Haritalarının Üretilmesi, Karadeniz Teknik Üniversitesi, Fen Bilimleri Enstitüsü, Doktora Tezi, Trabzon, 230 s.

Poon, J., Hoxley, M., ve Fuchs, W. (2011). Real estate education: an investigation of multiple stakeholder. Property Management, Vol. 29 Issue: $\quad 5$, pp.468-487, https://doi.org/10.1108/0263747111117814 6

SPL, (2018), Özet Veriler, 2018 Ocak-Haziran Dönemi, https://www.spl.com.tr/spl/eep/Specific/OEP /Upload/Kurumsal/\%C4\%B0statistikiRaporlar /2018/TR/1/mobile/index.html\#p=1

URL-1

https://www.spl.com.tr/spl/eep/kurumportal /Content/lisans-turleri/40/

URL-2

https://www.spl.com.tr/spl/eep/kurumportal 
/Content/lisanslama-sinavlarina-nasilbasvurulur/535/

URL-3

https://www.spl.com.tr/spl/eep/kurumportal /Content/tecrube-surelerine-iliskin-lisansgorev-tablosu/39/

URL-4 https://www.spl.com.tr/icerik/lisans-almasartlari

Sakınç, S.Ö., ve Coşkun, S. (2018). Gayrimenkul Değerlemesinin Önemi ve Çorum Merkezde Bir Uygulama, Strategic Researches III: Forom Local to Global (Edited By: Silvius Stanciu, Ali Riza Gökbunar, Turan Gündüz) p 32-48.

Solmaz, B., Arslan, A., Aydın, B. O., Duğan, Ö. (2012). Türkiye'de Halkla İlişkiler Lisans Eğitimi Üzerine Bir Değerlendirme, Selçuk Üniversitesi Sosyal Bilimler Enstitüsü Dergisi, 27, p. 253-269.

TDUB, (2019), 2018 Yılı Değerleme Sektörü Analizi, https://www.tdub.org.tr/Images/Uploads/TG BM\%20rapor\%202018_4\%20\%C3\%87EYREK (12AY)\%20revize\%20v5_AKT_01_03_2019.pdf
Vandell, K.D. (2007). Expanding the academic discipline of real estate valuation: A historical perspective with implications for the future. Journal of Property Investment \& Finance, Vol. 25 Issue: 5 , pp.427-443, https://doi.org/10.1108/1463578071077665 7

Warren-Myers, G. (2012). The value of sustainability in real estate: a review from a valuation perspective. Journal of Property Investment \& Finance, Vol. 30 Issue: 2, pp.115-144, https://doi.org/10.1108/1463578121120688 7

Yomralıoğlu, T., ve Nişancı, R. (2006). Türkiye'de Harita Mühendisliğinin Tașınmaz Değerlemesindeki Rolü, Rapor 1.0, p 1-21.

Yomralıoğlu, T., Nişancı, R., Çete, M., ve Candaş, E. (2011). “Dünya'da ve Türkiye'de taşınmaz değerlemesi", Türkiye'de Sürdürülebilir Arazi Yönetimi Çalıştayı, 26-27 Mayıs 2011, Okan Üniversitesi, İstanbul. 